
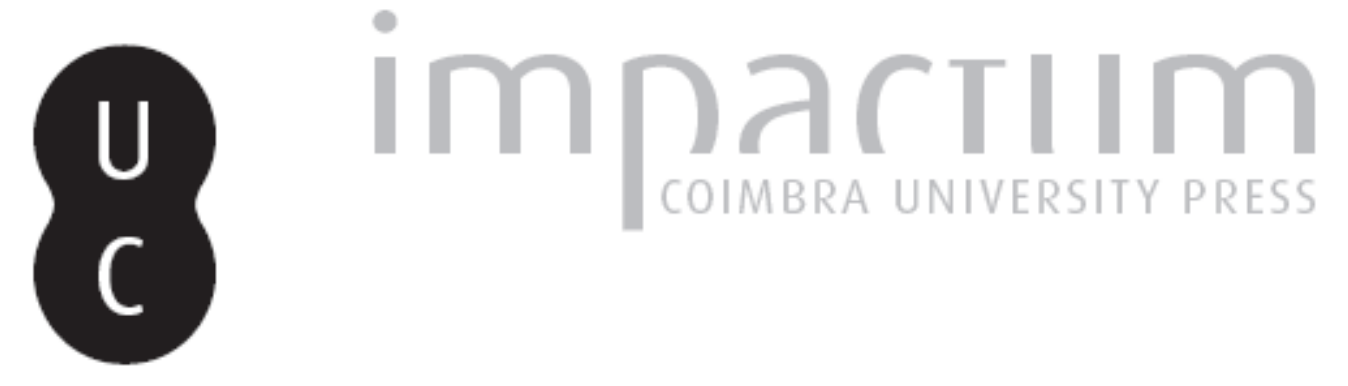

\title{
The theory and practice of ostracism in Plutarch's lives
}

\section{Autor(es): Beneker, Jeffrey}

Publicado por: International Plutarch Society

URL persistente:

URI:http://hdl.handle.net/10316.2/37588

DOI:

DOI:http://dx.doi.org/10.14195/0258-655X_2_1

Accessed : $\quad$ 26-Apr-2023 00:42:24

A navegação consulta e descarregamento dos títulos inseridos nas Bibliotecas Digitais UC Digitalis, UC Pombalina e UC Impactum, pressupõem a aceitação plena e sem reservas dos Termos e Condições de Uso destas Bibliotecas Digitais, disponíveis em https://digitalis.uc.pt/pt-pt/termos.

Conforme exposto nos referidos Termos e Condições de Uso, o descarregamento de títulos de acesso restrito requer uma licença válida de autorização devendo o utilizador aceder ao(s) documento(s) a partir de um endereço de IP da instituição detentora da supramencionada licença.

Ao utilizador é apenas permitido o descarregamento para uso pessoal, pelo que o emprego do(s) título(s) descarregado(s) para outro fim, designadamente comercial, carece de autorização do respetivo autor ou editor da obra.

Na medida em que todas as obras da UC Digitalis se encontram protegidas pelo Código do Direito de Autor e Direitos Conexos e demais legislação aplicável, toda a cópia, parcial ou total, deste documento, nos casos em que é legalmente admitida, deverá conter ou fazer-se acompanhar por este aviso. 


\section{Ploutarchos, n.s.}

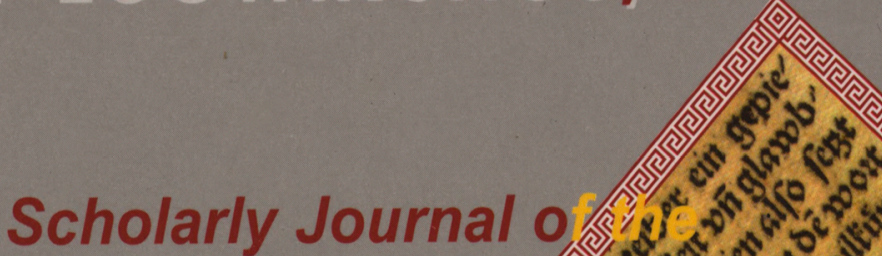

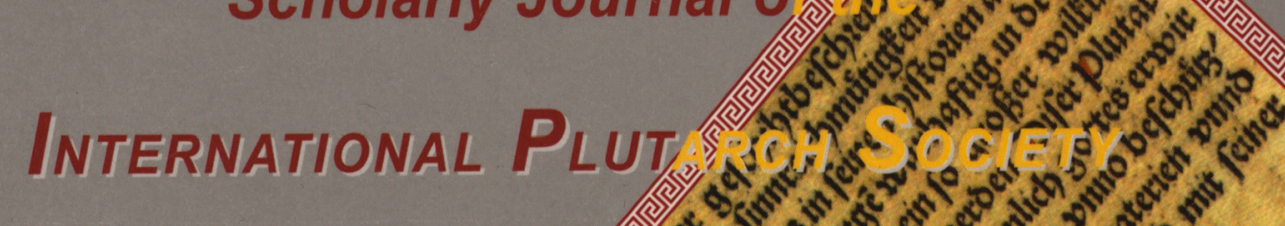

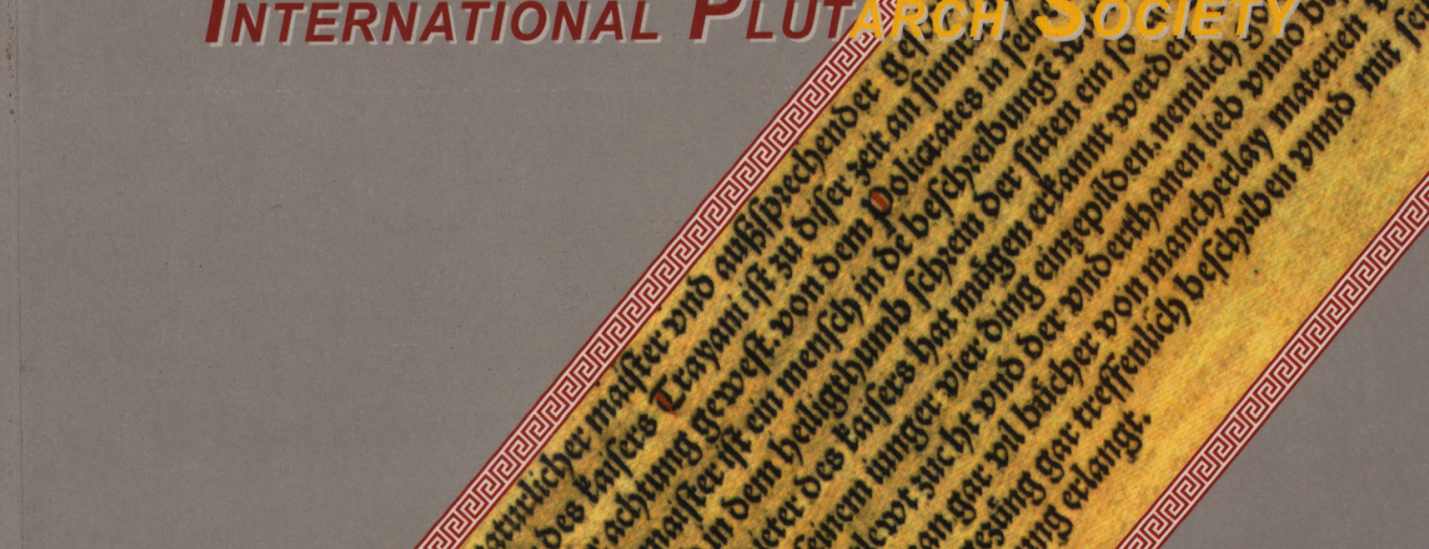




\title{
The Theory and Practice of Ostracism in Plutarch's Lives \\ by \\ Jeffrey Beneker \\ University of Iowa, USA
}

\begin{abstract}
This paper will examine Plutarch's accounts of ostracism and explore more fully how he thought it worked in theory and in practice. Accounts of ostracism are found in six of the Lives, all of fifth-century Athenians, and in one of the Moralia. These accounts often relate the same event, and so they allow us to see how Plutarch presents the same material from different perspectives. In this way we may view, for example, the ostracism of Aristides as it is presented in his Life but also as it appears in the Life of his opponent, Themistocles.
\end{abstract}

In this paper I will examine ostracism as it is appears in Plutarch's Lives. Accounts of ostracism are found in six of the Lives, all of fifth-century Athenians, and in one of the Moralia. These accounts often relate the same event, and so they allow us to see how Plutarch presents the same material from different perspectives. In fact, we can arrange our six Lives into three pairs, so that each pair presents two men who were political opponents and who appear as characters in each other's biographies. In this way we may view, for example, the ostracism of Aristides as it is presented in his Life but also as it appears in the Life of his opponent, Themistocles. We have a similar opportunity for the rivals Pericles and Cimon and for Nicias and Alcibiades ${ }^{1}$. Furthermore, an anecdote from the ostracism of Aristides, which appears in the Life, is also included in Plutarch's Regum et imperatorum apophthegmata ${ }^{2}$. The complete references are as follows:

Themistocles (5.7; 22.4-5) / Aristides (1.2-3, 7; 25.10; 26.5) / Regum et imperatorum apophthegmata (186a).

Pericles $(4.3 ; 7.1-2 ; 9.2-10.1 ; 14.1-$ 3 ; 16.3) / Cimon (17.3).

Nicias $(6.1-2 ; 11) /$ Alcibiades (13) / Comparatio Alcibiadis et Marii Coriolani (4.8).

At Arist. 7.3-4, Plutarch briefly describes the ostracism of Hyperbolus, an event that he treats at greater length in the Lives of Nicias and Alcibiades.

See M. BECK, 2002, on the authenticity of the prefatory letter to Trajan. The collection itself is considered genuine. 
Occurrences of ostracism in all of these works are of two types: Plutarch is either explaining in general how ostracism worked and why it was used, or he is relating the details of a particular case. When presenting the system in general, Plutarch describes it as a tool of the demos, used primarily to banish a man who has provoked the envy of the people. When writing about particular cases, however, Plutarch always presents ostracism as the tool of an individual or a faction, employed by politicians against their opponents as a way of eliminating rivals. This paper will examine Plutarch's accounts of ostracism and explore more fully how he thought it worked in theory and in practice.

We turn first to the political rivals Themistocles and Aristides. Toward the end of his career, Themistocles was banished by his fellow citizens, and Plutarch uses the occasion to explain why the Athenians would ostracize someone:

Then they [i.e. his fellow citizens] carried out an ostracism against him, curbing his high status and superiority, as they were accustomed to do against everyone whom they thought to be oppressive with his power and out of balance with respect to democratic equality. For banishment by ostracism was not a punishment, but an abatement and relief of the envy that takes pleasure in humbling those who are excelling and expresses its hostility in this dishonor (Them. 22.4-5) ${ }^{3}$.

According to this passage, the demos conducts an ostracism in response to an imbalance in the democratic make-up of the city, but behind the need to protect the democracy lies a desire to humble a man who has risen too high. Plutarch is probably supplementing the traditional explanation, such as that found in the Athenaion Politeia (22), where ostracism serves to eliminate men seen as a threat to the state ${ }^{4}$. In the Aristides, Plutarch is more specific about how one may become a target of the demos. In chapter one, where he discusses Aristides' finances, Plutarch responds to Demetrius of Phalerum, who said that Aristides must have been wealthy because he was ostracized, and ostracism was not aimed at the poor. In refuting this argument, Plutarch contends that there were several categories in which one could excel and then be banished for doing so:

See F. J. Frost, 1980, pp. 191-92, for a discussion of Plutarch's sources in writing this passage. According to Frost, there is no need to attribute Plutarch's view to a single source.

AthPol 22.6: "For three years they ostracized the supporters of the tyrants, for whose sake the law had been enacted, but later, in the fourth year, they began to remove anyone who appeared to be too great. Of those who were not associated with the tyranny, Xanthippus, son of Ariphron, was the first to be ostracized". Plutarch's assertion that envy also played a role is not necessarily original; J. L. MARR, 1998, p. 132, traces the idea back to Ephorus. 
Everyone who was thought to surpass the multitude in his reputation or birth or eloquence was subject to ostracism, just as even Damon, the teacher of Pericles, was ostracized because he was considered to be exceptionally wise (Arist. 1.7) .

In the general case, then, according to both of these passages, it is uncommon distinction that can stir the envy of the people and attract an ostracism. We will call this Plutarch's theoretical view.

- When Plutarch comes to narrating the actual ostracism of Aristides in chapter 7, he gives, in section 2, another general account, which is very similar to the one found in the Themistocles, although here he even more explicitly asserts that the purpose of ostracism is to vent the phthonos of the people ("They came from all over to the city and ostracized Aristides, calling their envy of his reputation a fear of tyranny", Arist. 7.2). In section 5 Plutarch explains the mechanics of the voting process. These passages frame a brief digression on how the ostracism of Hyperbolus brought the practice to an end; we will return to this later. Moving on to sections 7 and 8, Plutarch includes an anecdote that supports the notion of ostracism based on an elevated reputation. On the day of the vote, which he will lose, Aristides meets an illiterate farmer who hands him his ostracon and asks him to write the name "Aristides" on it:

When he wondered at this and asked whether Aristides had ever caused him any harm, the farmer said, “No. I don't even know the man, but I'm annoyed at hearing him called 'the Just' everywhere I go". When Aristides heard this, he made no reply, but he wrote his name on the ostracon and gave it back (Arist. 7.7-8)

This anecdote fits nicely with Plutarch's theoretical view of ostracism - reputation leading to envy and then to banishment. But if we return to the first section of this chapter, which we passed over, we learn that Aristides' reputation was not completely of his own making:

It happened for Aristides, who was at first beloved, that he was later envied on account of his surname ("the Just"), especially when Themistocles spread the word to the multitude that Aristides had annulled the courts by deciding and judging everything himself and that he had secretly established a monarchy, though without a bodyguard. And at this time also

5 But $c f$. Per. 4.3: "Though he used his lyre as cover, Damon did not escape notice: he was ostracized for being ambitious and supportive of tyranny and provided material to the comic poets"; see D. SANSONE, 1989, p. 178.

6 Cf. Reg. et imp. 186a. 
the demos, high-minded because of its victory [at Marathon] and thinking itself worthy of the greatest things, was in some way distressed by the name that had a reputation that lifted it above the multitude (Arist. 7.1).

We read here that Aristides had indeed become an object of envy because of his surname "the Just", but also that Themistocles turned public opinion against him by spreading the rumor that he had subverted the courts and was secretly establishing himself as monarch $^{7}$. Nonetheless, despite the efforts of Themistocles, Plutarch still presents the ostracism as conforming to his theoretical view by closing the section with these words: "They came from all over to the city and ostracized Aristides, calling their envy of his reputation a fear of tyranny". This statement reflects the sentiment of the passage from the Themistocles, where protection of the democracy was a shield for envy. Later in the Aristides, however, where Plutarch is not reporting the ostracism in conjunction with a theoretical statement, he confirms Themistocles' role by acknowledging that Aristides, "had been ostracized through him" (Arist. 25.10). Returning to the Themistocles, we find that there Plutarch has made the politician's involvement even more fundamental; he writes: "Growing powerful and pleasing the multitude, at last he overthrew Aristides and removed him through ostracism" (Them. 5.7) 8 .

These two Lives help us to observe a distinction between Plutarch's two views of ostracism. In theory, the envy of the people, disguised as concern for the public welfare, would lead to a vote against a distinguished individual; in practice, a politician could cast his rival as a danger to the state and turn the people against him. However, Plutarch's only attempt to reconcile these views is to ascribe the fear generated by Themistocles' charges to an underlying envy. While this connection is a bit tenuous, it does not signify, as Perrin wrote, that "as always, Plutarch fails to grasp the political significance" of ostracism?. Although ascribing an important role to envy, Plutarch nonetheless also reports that Themistocles was responsible for Aristides' banishment.

Plutarch's understanding of the political dimension is even more evident in the Pericles and Cimon, where

These charges are probably anachronistic; see F. J. Frost, 1980, p. 91; D. SANSONE, 1989, pp. 184-85.

8 This translation follows that of F. J. Frost, 1980, pp. 90-91, who argues that the verb

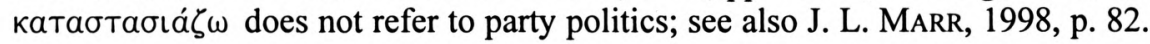

9

B. PERRIN, 1901, pp. 236-37. 
he describes two ostracisms without inserting theoretical explanations ${ }^{10}$. Plutarch writes, for instance, that the young Pericles is wary of politics on account of his background:

Because he had wealth, an illustrious family, and friends who were extremely powerful, he feared banishment by ostracism and did nothing political, but he was brave and adventurous in his military service (Per. 7.2) ${ }^{11}$.

In this passage, Plutarch takes for granted that the attributes he names can be damaging. Left unsaid is whether they would by themselves antagonize the demos or be used by an opponent to create resentment ${ }^{12}$. As the Life moves on to Pericles' battle against Cimon, however, we can see that such attributes are not always a hindrance to a political career. Cimon was wise enough to use his wealth to placate the demos. In fact, the qualities that were liabilities for Pericles -wealth and birth- become for Cimon weapons against ostracism. Cimon is able to out-demagogue Pericles by providing meals, clothing, and free access to his fields and orchards. As a result, Pericles is forced to resort to the distribution of public funds, which he does effectively. Plutarch continues:
Wherefore Pericles, having become more powerful with the demos, contended against the [Areopagus] council, so that most of its jurisdiction was taken away by Ephialtes, and Cimon was ostracized as being pro-Spartan and against the people, this despite the fact that he fell short of no one in wealth and birth, had won the finest victories over the barbarians, and had filled the city with great wealth and spoils, as is written in his Life. So great was Pericles' power among the demos (Per. 9.5).

We note here the qualifying phrase, "despite the fact that he fell short of no one in wealth and birth". Cimon has turned what are normally envy-provoking attributes into a means for stabilizing his position; nor is there any indication that his military success inspired resentment. In order to oust him, Pericles must charge him with sympathy for Sparta and animosity toward the demos. Plutarch reports the same accusations in the Life of Cimon, although there he assigns credit for the ostracism to the people rather than to Pericles alone. However, he also calls the charge of disloyalty a "trifling pretext", noting how it was made amidst the anti-Spartan

Plutarch does in fact make brief references at Cimon 17.3 and Per. 10.1 to the institution of ostracism, but only to provide the duration of the banishment.

11 Nicias also keeps a low profile in order to avoid the ill-will of the people (Nic. 6.1-2).

12 In either case, as P. A. STADTER, 1989, p. 88, notes, Pericles had good reason to be wary, since his maternal uncle Megacles and his father Xanthippus had both been ostracized (in 486 and 484, respectively). 
attitude which arose after the Athenians were turned away from Ithome (Cimon 17.3). In both versions, however, the reality differs from the theory set forth in the Themistocles and Aristides in that Cimon is ostracized for his unpopular position rather than his high standing.

In Plutarch's account of the struggle between Pericles and Thucydides, son of Melesias, ostracism is an undisguised political tool. However, it nonetheless must be wielded with the backing of the people. With Cimon removed, Pericles asserts his control over the demos, and when he has gained confidence in his authority, he decides to face Thucydides in an ostracism-showdown:

When the supporters of Thucydides were condemning Pericles for throwing away money and wasting revenues, he asked the people in the assembly whether they thought he was over-spending. When they answered that his spending was excessive, he said, "Well, then, let the expenses be met not by you, but by me, and I shall put my own inscription on the monuments". When he said this, they were either amazed at his boldness or jealous of the glory of the works, and they raised a cry, bidding him to spend from the public funds and to spare nothing in his administration. And finally, taking a risk and challenging Thucydides to a contest of ostracism, he banished him and also destroyed the opposing faction (Per. 14.1-3).

The case of Thucydides demonstrates the power of ostracism as a political weapon, but also the prerogative retained by the demos. The arrangement of this passage, with its emphasis on Pericles' management of the assembly, shows that Pericles delayed his attack on Thucydides until he felt confident that the people would respond to his initiative. Even then, however, Plutarch acknowledges that he was taking a risk.

In reporting these two ostracisms, Plutarch makes no reference to the envy of the people: Cimon is banished for his unpopular political position, and the actual reason for the vote against Thucydides is buried beneath Pericles' great influence. When theoretical statements are absent, it appears that Plutarch is willing to present ostracism as a purely political process.

Turning to our final pair of Lives, the Nicias and Alcibiades, we find the theoretical and the practical views intertwined. Both of these Lives relate the ostracism of Hyperbolus in some detail. Leaving aside the question of Plutarch's accuracy and his sources, we still have a vivid illustration of how an ostracism could be manipulated ${ }^{13}$. Plutarch states ical details in his handling of the Hyperbolus incident. For a general a treatment and bibliography, see P. J. RHODES, 1994. 
the situation succinctly in the Alcibiades:

At that time, then, having been persuaded by him [i.e. Hyperbolus], they were about to hold an ostracism, by which means they usually restrained and banished one of the citizens who excelled in reputation and influence; in this way they would alleviate their envy rather than their fear. And when it was evident that the vote would go against one of the three [Nicias, Alcibiades, or Phaeax], Alcibiades brought the factions together, and having consulted with Nicias, he turned the ostracism back against Hyperbolus (Alc. 13.6-7).

In this passage, Plutarch is once again asserting that ostracism is really for the relief of envy rather than for the protection of the state, as when the Athenians disguised their malice towards Aristides by calling it fear of tyranny. He makes a similar statement in the Nicias, although there he says that those suspected on account of their reputation as well as those envied for their wealth are subject to ostracism (Nic. 11.1). What is curious in this case is that at Alcibiades 13.4, previous to the passage quoted above, Plutarch describes Hyperbolus as wicked and constantly mocked by the comic poets, and he refers the reader to Thucydides (the historian) who writes in a different context that Hyperbolus was ostracized not out fear of his power or stature but on account of his wickedness and the shame he brought to the city ${ }^{14}$. While Plutarch would agree that ostracism was not aimed at men solely out of fear, his theoretical statements cannot explain a banishment on the basis of wickedness or shame.

In fact, there is an inconsistency in Plutarch's own narrative as it stands in both versions, as well as in the summary that appears in the Aristides. In the Alcibiades he writes that, "Alcibiades drove out Hyperbolus, who would not have expected it, for no one common or disreputable received this chastisement" (Alc. 13.8). In fact he was so base that he disgraced the institution of ostracism and caused it to be abandoned, a supposition that Plutarch supports by quoting the comic poet Plato:

Indeed he experienced things worthy of those who preceded him, but those things were not worthy of him or his markings, for ostracism was not invented for the likes of him (Alc. 13.9; also Nic. 11.7).

Hyperbolus' qualities are just the opposite of those that attracted ostracism in Plutarch's theoretical state-

Thuc. 8.73.3, which is not a report of the quarrel between Alcibiades and Nicias; see also D. SANSONE, 1989, p. 185; W. R. ConNOR, 1971, p. 81. 
JEFFREY BENEKER

ments in the Themistocles and Aristides, and the opposite as well of what caused Pericles to lie low. Missing from Plutarch's accounts are the details of how the campaign against Hyperbolus was framed. This is the general disconnection that runs through each of these three pairs of Lives. Plutarch maintains his theoretical view, that ostracism relieved envy, as opposed to alleviating fear caused by a threat to the state, but his only attempt to reconcile the theory with practice occurred in the case of Aristides. Implicit in that case, howev$\mathrm{er}$, is the notion that fear could motivate a campaign of ostracism, even if the people voted ostensibly to protect the state but really to vent their jealously. The argument of a threat to the state was clearly used against Cimon, and probably against Thucydides, son of Melesias, as well, and we can see how the people might harbor an underlying envy in both of those cases. But with Hyperbolus, by Plutarch's own testimony, there was no question of an exalted reputation. In this case, we must leave the theory and the practice unresolved and wonder how exactly Alcibiades and Nicias convinced the demos to vote against Hyperbolus ${ }^{15}$.

\section{WORKS Cited}

BECK, M.,

- "Plutarch to Trajan: The Dedicatory Letter and the Apophthegmata Collection", in P. A. STADTER \& L. VAN DER STOCKT (eds.), Sage and Emperor: Plutarch, Greek Intellectuals, \& Roman Power in the Time of Trajan (98-117 AD), Leuven, 2002, 163-73.

CONNOR, W. R.,

- The New Politicians of Fifth-Century Athens, Princeton, 1971.

Frost, F. J.,

- Plutarch's Themistocles: A Historical Commentary, Princeton, 1980.

MARR, J. L.,

- Plutarch: Life of Themistocles, Warminster, 1998.

Pelling, C.,

- Literary Texts and the Greek Historian, London, 2000.

PERrin, B.,

- Plutarch's Themistocles and Aristides, New York, 1901.

RHODES, P. J.,

- "The Ostracism of Hyperbolus", in R. OSBORNE \& S. HORNBLOWER (eds.), $R i$ tual, Finance, Politics: Athenian Democratic Accounts Presented to David Lewis, Oxford, 1994, pp. 85-98.

SANSONE, D,.

- Plutarch: The Lives of Aristeides and Cato, Warminster, 1989.

STADTER, P. A.,

- A Commentary on Plutarch's Pericles, Chapel Hill, NC, 1989.

C. Pelling, 2000, pp. 51-2, sets forth in more detail the obscurity of this account: Plutarch not only passes over the complexities of organizing such a vote, but his argument that the institution of ostracism was subsequently abandoned appears to be based only on the fragment from Plato, the comic poet; his focus on Hyperbolus as a scoundrel rather than a politician fails "to capture the reasons for holding an ostracism or the motives leading a voter to choose his victim". 